\title{
THE INFLUENCE OF PUBLIC FACILITIES AND AMENITIES ON SPATIAL PATTERN IN THE NORTHERN AREA OF BANDUNG: AN AGENT BASED MODELLING APPROACH
}

\author{
Budhy Soeksmantono ${ }^{1}$, Ketut Wikantika ${ }^{1}$ \\ ${ }^{1}$ Remote sensing and GIS Research Group, Institut Teknologi Bandung (ITB), Jl. Ganesha 10, \\ Bandung 40132, West Java, Indonesia \\ Email:soeksmantono@gd.itb.ac.id,
}

KEY WORDS: Public Facilities and Amenities, Spatial Pattern, Agent Based Model

\begin{abstract}
Bandung is one of the largest growing cities in Indonesia with a high human population growth and density. The northern part which has hilly terrain with nice and beautiful scenery attracted many people to live there. This condition puts pressure to this area. Local government is very concerned with this water catchment area due to its rapid land use change. Some models have been developed to identify, monitor and predict a change on spatial pattern in the future, but none of them incorporate spatial externality and agent interaction in the built model. The aim of this paper is to explore how these two items can affect a spatial pattern of the study area. The study focuses on residential area and the simulation model is developed based on an agent based modeling. The model is used to simulate the dynamic spatial pattern. The model is cells based and it represents geographic data, i.e. land cover, terrain, location of public facilities. The cell characteristic is influenced by and influence to the neighboring cells. The hypothetical agent took a decision to seek a place to settle based on proximity of public facilities and amenities. They interact to another agent and cell under its control. Probabilistic decision-making used in the interaction process. The simulation result demonstrates that this approach can capture spatial change based on the human environment interaction.
\end{abstract}

\section{INTRODUCTION}

Bandung is the capital city of West Java Province. It's surrounded by mountain and located at more than $700 \mathrm{~m}$ above mean sea level. This area has a third largest human population in Indonesia and it's increased significantly within the last two decades. One of the population growth consequences is the housing demand. This demand puts pressure to the area and makes land use/cover change. The house location is selected not only based on physical criteria, but also preference for amenities. The city-view from the top/side of the hill is one of the preference that influenced. This kind of amenities is exist in the northern part of Bandung. This advantage attracts many people to live there, increase a residential area and reduce water infiltration. This phenomenon should be monitored properly to avoid negative consequences in the future.

Some models have been developed to identify, monitor and predict a future spatial pattern. Deliar (2010), develop model by using Markov chain and cellular automata to predict land cover changes in Bandung area. While another model uses remote sensing and time series spatial data to identify, monitor and predict the changes. Those models provide information derived from spatial data and none of them is considered an amenities which motivate people to choose their location. Based on residential physical criteria, the northern part of Bandung is not the first rank for residential location but this area provides city-view amenities which is unique compared with another place around Bandung. This factor gives significant contribution on the location choice and spatial pattern in general. To capture this phenomena, a household who looking for a place to live, underlies factor, interaction between him and the landscape should be included into the model. The approach that can be used to model this phenomena is an agent based modelling (Parker et al., 2003).

\section{MATERIALS AND METHODS}

\subsection{Theoretical Basis}

Agent based modelling is a concept from computational science that designed a system composed of intelligent agent that interact in a virtual environment through a computer program. This approach serves as a "laboratory" to explore and simulate the relationship and interaction between agent and environment. The agent is a representation of autonomous decision maker. The agent characteristic of taking a decision is heuristic and bounded rationality is. Agent move around and interact with the environment. This environment composed of two-dimensional square lattice grid cell. 
The agent and cell can be interacting and influence each other. Related to the study, an agent represents a household who looking for a house location based on they preference. Cell represent geographic data of the study area.

\subsection{Datasets Used}

We choose the northern part of Bandung as study are due to the rapid land use changes (Figure 1.). The study area is located on the northern area of Bandung City. It's covered approx. 3679 Ha and bordered by coordinate $\quad(786719.78$, 9244811.588) at upper left corner and coordinate (798270.220, 9234492.412) at lower right corner in the UTM 48S system. There are four types of spatial data used in the study, that is land cover, DEM, distance to the road network and distance to public service. These data were derived from topographic vector map in 1:25.000 scale that is made in 2005. It converted to raster data in $10 \mathrm{~m}$ spatial resolution. There are eight classes land

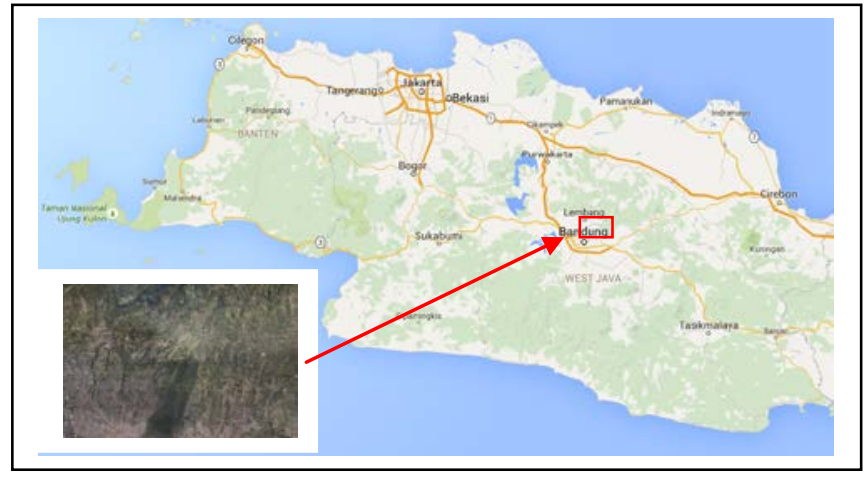

Figure 1. Northern Area of Bandung cover types were used, including water area. polated from contour data. Distance to the road network and public service is calculated as Euclidian distance. The illustration of these data can be seen in figure 2. The orthophoto data derived from photogrametric process that is made in 2013 used for validation. Idrisi selva used to prepare all spatial data and netlogo 5.1.0 platform used for modelling the behaviour and interaction of an agent and landscape.

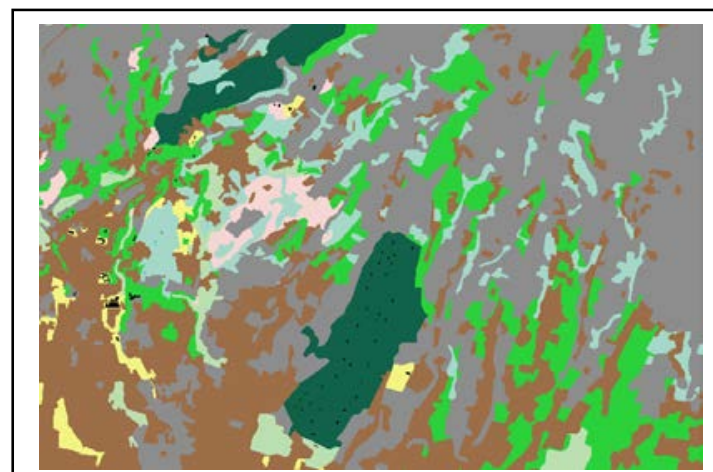

(а.)

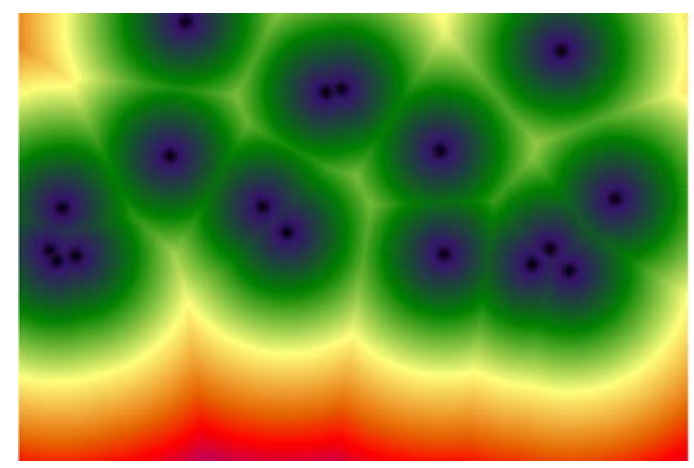

(c.)

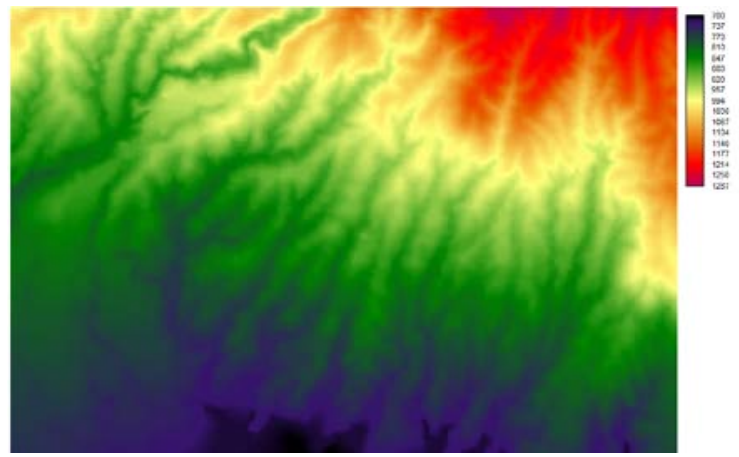

(b.)

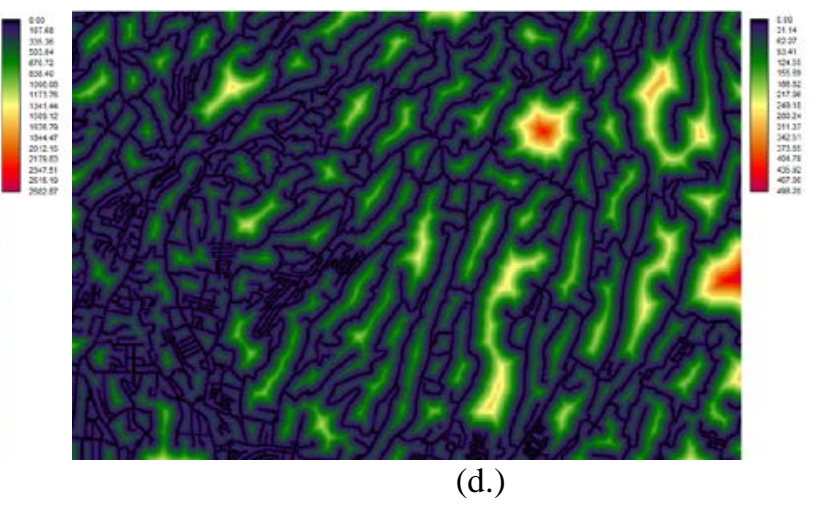

(d.)

Figure 2. (a.) Land cover. (b.) DEM. (c.) Distance to the public service. (d.) Distance to the road network

\subsection{Procedure}

In this paper, we build a model which incorporates household preference (city-view amenities and proximity to public service) on the location choice for residential. The agent represents a household. Cell represent a land cover, DEM, distance to the public service and distance to the road network with $10 \mathrm{~m}$ spatial resolution. Each 
cell consists of these four information and can be accessed by any agent. City-view amenities means the agent can see the city clearly from the place where they live. The place which meets this criteria is located on or close to the top of the hill, not in the valley. Logically, live close to residential areas and the road network is the first consideration of household agent on location choice before another factor. This logical thinking is implemented into three different options when the agent makes location choice. Each option has different range of probability and sequential variable choice. The agent chooses one of them randomly. First option, the agent chooses the cell location based on the amount of residential neighbor cell only. If there is four residential cell or more in radius (cell window three times three), the agent picked one of them. Second option, the agent started to choose a cell with maximum amount of residential neighbor in radius. In this group of cell, the agent then chooses the closest cell to the road network, closest to the public service and the highest terrain height. If there is more than one cell, the agent will pick it randomly. Third option, distance to road network is the first choice. In this group of cell, the agent then chooses a cell with maximum amount of residential neighbor in radius, closest to the public service and the highest terrain height. If there is more than one cell, the agent will pick it randomly. The cell landscape, then converted to residential after household agent occupied the cell. The range probability for first, second and third option are $0.1,0.5$ and 0.4 respectively. The initial condition of model simulation used data that is made in 2005. The simulation result, then validates by using orthophoto data that is made in 2013.

\section{RESULTS AND DISCUSSION}

Figure 3 shows the result of land cover after simulation. Cell with color magenta is a cell which is converted to residential. In general, we can see that spatial pattern of residential area form a line pattern following the road

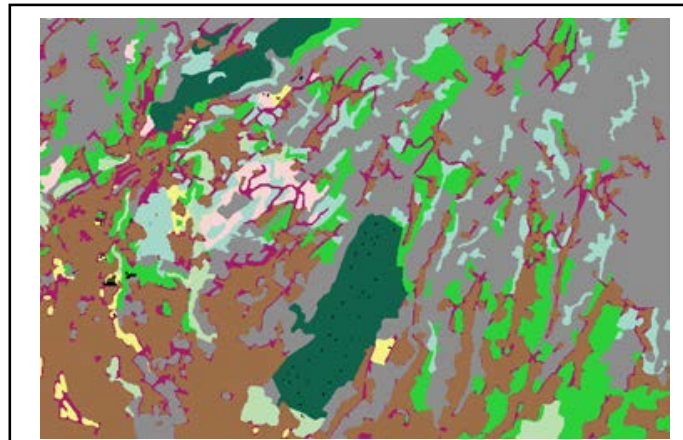

(a.)

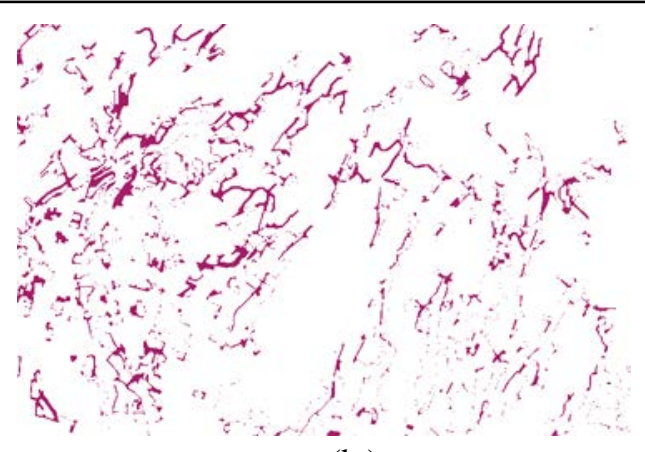

(b.)

Figure 3. (a.) Land cover after simulation. (b.) Spatial pattern for new residential area

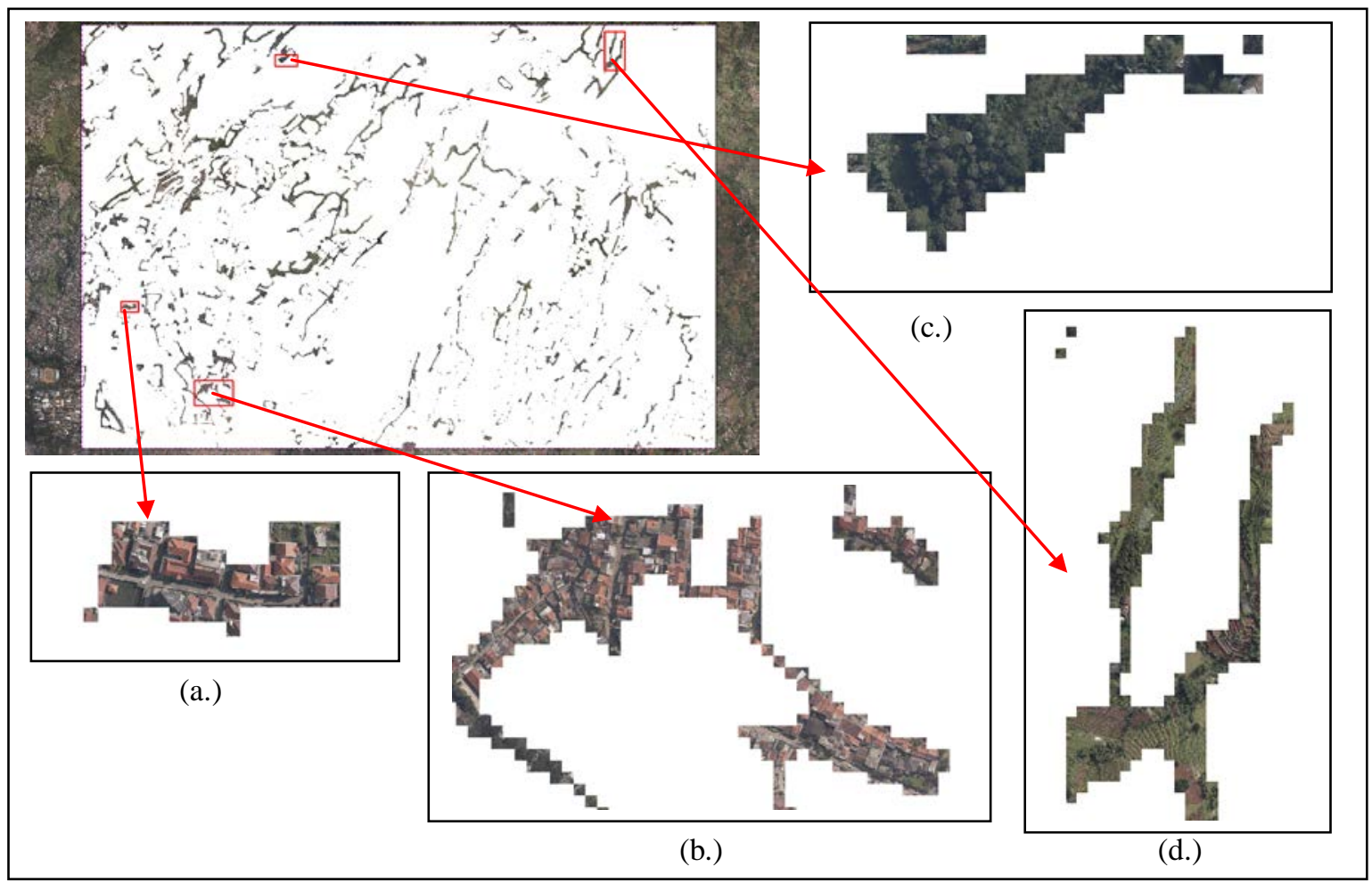

Figure 4. Overlay between new residential area and orthophoto 
network. There are approximately $40 \%$ of the new residential cell on land cover after simulation, match with residential area on orthophoto (Figure 4. (a.) and (b.)), while the remaining $60 \%$ are not matched (Figure 4. (c.) and (d.)).

\section{CONCLUSION}

In this study, we develop a simple agent based model to simulate the residential location choice by household, based on their non-spatial preferences. The model needs to be improved, so it can capture more complex phenomena which are occurring in the study area and increase the accuracy result.

\section{REFERENCES}

Dawn C. Parker, Steven M. Manson, Marco A. Janssen, Matthew J. Hoffmann, Peter Deadman., 2003. Multiagent systems for the simulation of land-use and land-cover change: a review. Annals of the Association of American Geographers, 93 (2), 314-337.

Deliar. A., 2010. Hybrid modelling in the prediction of land cover change. Dissertation.

Eastman. J.R., 2012. Idrisi selva manual. Clark Labs, Clark University. Worcester. USA

Wilensky. U,. 1999. NetLogo. http://ccl.northwestern.edu/netlogo/. Center for Connected Learning and Computer-Based Modeling, Northwestern University, Evanston, IL. 